\title{
Lesotho's white gold: the political ecology of temporality and the economy of anticipation in resource extraction and large dam infrastructural projects
}

\author{
Yvonne A. Braun ${ }^{1}$ \\ University of Oregon, USA
}

\begin{abstract}
The construction phases of large dam and infrastructural projects often extend over long periods of time, creating social, environmental, cultural, political, and economic consequences in the proximate communities and landscapes. The temporality of the phases of the project - from planning to construction to post-construction - reveal more layered and wide-ranging consequences from the social and environmental changes that result, sharpened by greater attention to how these changes unfold across multiple timescales and sites of the project. Using the case study of the Lesotho Highlands Water Project (LHWP), I draw on a political ecology approach that uses longitudinal data, including interviews, document analysis, and ethnographic fieldwork conducted in Lesotho since 1997, to illustrate how active project narratives draw from and promulgate an affective economy of anticipation in ways that aim to both sustain the hope of people affected by the project and contain their criticism of the project amidst a continued investment by the state in the expansion of the LHWP. As people directly affected experience disjunctures between the promises and the realities of the project over time, subsequent phases of the project are simultaneously renewed and recast through a logic of improvement that emphasizes changes in the implementation of the project while continuing to invest in the future imaginary of development that requires going forward with project plans. A logic of continuity and improvement structures this continued commitment to the capital intensive LHWP through the strategic mobilization of phases that scaffold both the material and physical dimensions of the project, but also the affective and anticipatory hopes of prosperity that the project represents. In this case, it also reveals how project authorities weave these dimensions - the material and the aspirational - into specific planned changes and improvements to address previous and ongoing concerns as projects progress over time. This longitudinal approach demonstrates the importance of temporal and affective dimensions to our understanding of the complex, multi-faceted consequences of resource extractive mega-dam projects such as the LHWP, particularly as they further rationalize the resource extractive approach to economic development in the region.
\end{abstract}

Keywords: development, dams, infrastructure, political ecology, temporality, affect, resource extraction, economy of anticipation, displacement, construction, Lesotho, Southern Africa

\section{Résumé}

Il y a de longues conséquences sociales, environnementales, culturelles, politiques et économiques dans les communautés et les paysages voisins qui résultent des phases de construction de grands barrages et de projets d'infrastructure. La temporalité des phases du projet - de la planification à la construction en passant par la post-construction - révèle des conséquences étagées et étendues. Celles-ci sont rendues plus visibles par l'attention portée à la manière dont ces changements se déroulent sur plusieurs échelles de temps et sites. À l'aide d'une étude de cas du Lesotho Highlands Water Project (LHWP), je m'appuie sur une approche d'écologie politique qui utilise des données longitudinales, y compris des entretiens, des analyses de documents et des travaux ethnographiques sur le terrain menés au Lesotho depuis 1997. J'illustre comment les récits du projet s'inspirent d'un économie affectif d'anticipation, à entretenir l'espoir des personnes concernées par le projet et à

\footnotetext{
${ }^{1}$ Dr. Yvonne A. Braun, Professor, Department of Global Studies, University of Oregon, USA. Email: ybraun "at" uoregon.edu. I would like to acknowledge funding from the National Science Foundation and the U.S. Fulbright Student Program, and the generous support from local organizations and interviewees who supported this work. I am particularly grateful for the constructive feedback on earlier drafts from three anonymous reviewers and the two Special Section guest editors. This is the second article in Ashley Fent and Erik Kojola (eds.) 2020. "Political Ecologies of Time and Temporality in Resource Extraction", Special Section of the Journal of Political Ecology 27: 819-938.
} 
contenir leurs critiques. Ceci est important alors que l'État continue d'investir dans l'expansion du LHWP. Les personnes directement touchées par les barrages et l'inondation de leurs terres ont trouvé que les promesses du projet étaient meilleures que la réalité. Une logique d'amélioration guide les phases ultérieures du projet, et il est simultanément renouvelé et refondu. Il y a des changements dans la mise en œuvre des étapes ultérieures, tout en continuant à vendre un imaginaire de développement futur. Une logique de continuité et d'amélioration structure un engagement continu dans le LHWP à travers la mobilisation stratégique des dimensions matérielles et physiques du projet en une série de phases, tout en promettant la prospérité. Je discute de la façon dont les responsables de projet intègrent ces dimensions - le matériel et les aspirations - dans des changements et des améliorations planifiés pour répondre aux préoccupations précédentes et en cours au fur et à mesure que les projets progressent au fil du temps. Cette approche longitudinale démontre l'importance des dimensions temporelles et affectives des projets de méga-barrages d'extraction de ressources complexes et multiformes. Le LHWP rationalise davantage son approche d'extraction des ressources pour le développement économique de la région.

Mots clés: développement, barrages, infrastructures, écologie politique, temporalité, affect, extraction de ressources, économie d'anticipation, déplacement, construction, Lesotho, Afrique australe

\section{Resumen}

Las etapas de construcción de grandes presas y proyectos de infraestructura con frecuencia se extienden por largos periodos de tiempo, lo que lleva a consecuencias sociales, ambientales, culturales, políticas y económicas en comunidades y paisajes aledaños. Las temporalidades de las distintas etapas - desde la planeación hasta la construcción y la post-construcción - revelan consecuencias más estratificadas y de gran alcance desde los cambios sociales y ambientales resultantes, los cuales, son acentuados por una mayor atención a cómo estos cambios se desarrollan a través de múltiples escalas de tiempo y sitios del proyecto. Para el caso de estudio del Proyecto Hidrológico del Altiplano de Lesoto (LHWP), me baso en una aproximación desde la ecología política con datos longitudinales, incluyendo entrevistas, análisis de documentos, trabajo etnográfico realizado en Lesoto desde 1997. Así, ilustro cómo narrativas activas de proyectos están basadas y promueven una economía afectiva de anticipación, de manera que apuntan tanto mantener la esperanza de los afectados por el proyecto y contener sus críticas en medio de una continua inversión del estado en la expansión de LHWP. Mientras la gente directamente afectada experimenta una dislocación entre las promesas y las realidades del proyecto a través del tiempo, las fases subsecuentes del proyecto son simultáneamente renovadas y reestructuradas con una lógica de mejoramiento que enfatiza los cambios en la implementación del proyecto mientras se continúa invirtiendo en el imaginario futuro de desarrollo que requiere seguir adelante con los planes. Una lógica de continuidad y mejoramiento estructura este compromiso continuo con el intensivo en capital LHWP a través de la movilización estratégica de las etapas, lo que proporciona tanto las dimensiones materiales, como las físicas del proyecto, aunque también las esperanzas afectivas y anticipadas de prosperidad que el proyecto representa. En este caso, también se revela cómo las autoridades del proyecto tejen estas dimensiones material y aspiracional- en cambios específicamente planeados y mejoras para atender preocupaciones pasadas y presentes, mientras el proyecto avanza. Esta aproximación longitudinal demuestra la importancia de las dimensiones temporales y afectivas para nuestra percepción de las complejas y multifacéticas consecuencias de los proyectos de mega presas extractivas de recursos, tal como LHWP, específicamente, mientras más se siguen racionalizando las aproximaciones extractivistas de recursos para el desarrollo económico de la región.

Palabras clave: desarrollo, presas, infraestructura, ecología política, temporalidad, afectividad, extracción de recursos, economía de anticipación, desplazamiento, construcción, Lesoto, Sudáfrica.

\section{Introduction}

The construction phases of large dam and infrastructural projects often extend over long periods of time, creating social, environmental, cultural, political, and economic consequences in the proximate communities and landscapes. The temporality of large dam projects has been underexplored, as the final consequences of large dams have typically been the focus - either the hopeful possibilities from the "local pain for national gain" (Roy 2000), or the enormous social cost from displacement (Scudder 2012). While the latter outcomes are important, a temporal approach to understanding mega-projects reveals that there are ongoing and dynamic series of consequences over time, and which begin before construction starts. These capital-intensive projects 
are planned well in advance, with siting of the dams initiating years of disinvestment into areas that are planned to be disrupted by eventual large-scale construction (Scudder 2006). The temporality of the phases of the project - from planning to construction to post-construction - reveal more layered and wide-ranging consequences from the social and environmental changes that result, sharpened by greater attention to how these changes unfold across multiple timescales and sites of the project.

I use a political ecology approach to further refine the study of temporality by exploring how discourses about large-scale projects draw upon and mobilize affective narratives of anticipation and hope over the course of the project. These narratives typically include promises of future benefits and prosperity for locally affected people and for the nation, a type of future imaginary of development that works to garner or coerce support (Li 2007), or perhaps acquiescence (Cross 2015), in the early stages of construction. As people directly affected experience disjunctures between the promises and the realities of the project over time, subsequent phases of the project are simultaneously renewed and recast through a "logic of improvement", a narrative that emphasizes beneficial changes in project implementation while continuing to invest in the future imaginary of development that requires going forward with project plans. The logic of improvement reflects and constitutes an "economy of anticipation" (Cross 2015) that fuels the future imaginary of development in two ways: it becomes a means to renew people's hope in the eventual deliverance on the project's promises of prosperity, and a means to dismiss complaints about the project during implementation before final gains can be achieved. In large-scale projects with multiple phases, the logic of improvement and economy of anticipation are hinged to the necessity of subsequent phases to realize the project's potential, even if earlier phases have had problems or have not achieved expected results. These affective dimensions of large-scale projects and their relationship to temporality are underexplored in studies of resource extraction and development, and I explore these here through a case study of the Lesotho Highlands Water Project (LHWP), a transnational water scheme between South Africa and Lesotho.

Resource extraction has been central to economic development in Southern Africa, and particularly to the political and economic dominance of South Africa since colonial times. In the 1980s, the apartheid government of South Africa saw water scarcity as threatening continued industrial development, particularly in the Gauteng region. The apartheid system of South Africa and Lesotho's harboring of exiled African National Congress (ANC) members created tense relations between the two countries during this period (Davidsen 2006). Despite this enmity, the apartheid government of South Africa and the new military government of Lesotho under General Major Lekhanya - shortly after the coup d'etat of President Leabua Jonathan - entered into a controversial bilateral agreement in 1986 to pursue the LHWP. The mega-project was proposed as a five dam and tunneling infrastructural project to capture, transfer, and sell water from the "water rich mountain areas in Lesotho via the Ash River to the Vaal Dam in South Africa where water is pumped to Gauteng" (Davidsen 2006: 49). The bilateral treaty established a parastatal authority in each country - in Lesotho, the Lesotho Highlands Development Authority (LHDA) - to implement the project over four phases, with most of the construction and direct impacts in Lesotho. The treaty also included hydropower generation originally planned to be paid for by the royalties from the sale of water from Lesotho to South Africa. Phase 1A and 1B are completed, and Phase 2 is currently underway.

Within the context of Lesotho, the LHWP was designed as a resource extractive approach to national development which had hopeful resonance within the social and economic histories of the Southern African region. The project was heralded as an opportunity to generate national revenues through the sale of water, referred to as Lesotho's "white gold", a seemingly abundant and un(der)-utilized natural resource from the perspective of project proponents. However, highland rivers were and continue to be critical elements of cultural, social, and economic life in the rural communities in which these rivers flow. These relationships are shaped over time, and become re-organized in relation to the interactive phases of the LHWP in their lives.

For highlands residents directly affected by the project, the LHWP was built on promises of a future imaginary of employment and prosperity via "white gold." This narrative is re-told over the course of the project through a logic of improvement that continues to bolster and string together hopes of past promises, which low level development workers and government officials alike continue to assure them will be kept in some near future by largely staying the course with the LHWP. In Phase 2, project proponents assert that a number of changes are being made to the practices and processes of the implementation of the project amidst a continued 
investment by the state in the expansion of the LHWP, further rationalizing the resource extractive approach to economic development in the region.

In this article, I draw on a political ecology approach that uses longitudinal data, including interviews, document analysis, and ethnographic fieldwork conducted in Lesotho since 1997, to illustrate how active project narratives draw from and promulgate the affective economy of anticipation in ways that aim to both sustain hope and contain criticism of the project over time. This longitudinal approach demonstrates the importance of temporal and affective dimensions to our understanding of the complex, multi-faceted consequences of resource extractive mega-dam projects such as the LHWP. As large dams continue to be built in the developing world, and at a faster rate than any other time, and as large dams are re-cast as carbon-low, green energy solutions in the era of climate change (Bromber et al. 2014), this research extends important theoretical and empirical insights to better capture how the social and environmental costs of these mega-projects unfold dynamically over time, in place, and in relation to the anticipatory aspirations attached to resource extraction and development.

\section{Literature review}

Large-scale dam and infrastructure projects remain a common and controversial means toward development and poverty reduction in the Global South (Scudder 2006, 2012; World Commission on Dams (WCD) 2000). The social and environmental consequences of large dams have been extensively debated (Kirchherr and Charles 2016; Tilt et al. 2009), with critics arguing the local effects - resettlement, dislocation, decreased access to natural resources - reveal the contradictions and flawed logic of dams as national development solutions (Scudder 2006). Typically the poor and marginalized absorb a disproportionate share of the costs of these projects (Bromber et al. 2014; Roy 2000), such as development-induced resettlement (Hussain 2008), leading to local and global opposition in India (Khagram 2004) and in Chile (Borgias and Braun 2017), and long-term consequences, such as higher rates of poverty for successive generations as the Gwembe Tonga experienced after relocation for Zambia's Kariba Dam (Scudder 2006).

As we consider large-scale dam infrastructural projects as approaches to national development, which characterizes Lesotho, we are compelled to understand these as resource extractive projects that draw on and reorganize access to natural resources, unfolding with dynamic social and environmental impacts over time (Braun 2006). Resource extractive approaches emphasize the value of natural resources through utilitarian and capitalistic means, and seek to privilege market values over other uses and claims. The literature on large dams has noted a general lack of political will to fully address the social and environmental consequences of dispossession and displacement in the context of large-scale dam building and resource extractive projects more generally (Scudder 2006, 2012).

As the significant social and environmental consequences of dams are justified through narratives that promote the benefits for national development, the communities that absorb the most direct consequences of large-scale development become part of a rationale of "local pain for national gain", or of what is best for "the greater common good" (Roy 2000). Large-scale dam projects are almost without exception sited in poor, rural, and politically, ethnically, or socially marginalized communities, ironically structuring the "local pain" to disproportionately affect already disempowered populations (Braun 2015; Bromber et al. 2014). I argue these patterns associated with large-scale development, such as the building of mega-dams, are best interpreted through the combined fields of development studies and political ecology in order to understand the relations of power and how they shape the planning and implementation of how environmental goods and resources are valued and rationalized over time.

\section{Large-scale infrastructure and development}

River basin development, like the construction of large dams, employs a utilitarian technological and market approach, generally valuing rivers and river basins through the exclusive lens of technical and marketbased development (Molle et al. 2009). While there have been significant practical benefits to this approach, critics argue that it marginalizes alternative framings of these human relationships and meanings to an 
imperative to commodify and develop these water resources, often with unintended and unequal outcomes (Boelens et al. 2016).

The state is not a passive agent in this process as it enacts legislation and policy, practices that facilitate the transformation of spaces toward the interests of capital and development, such as the building of massive infrastructural projects (Purcell 2008). These facilitative practices represent the normative alignment between the interests of capital and the state (Dreiling and Darves 2011), which assumes that it in the best interest of the people to make the changes needed to maintain a competitive edge in the global economy (Purcell 2008). The integration of this perspective into state policies has led to an undervaluing of local economies, landscapes and societies, and obscures the marginalization and dispossession that occurs through the implementation of development projects, particularly large-scale initiatives involving resource extraction and displacement.

The unintended consequences of such large-scale development projects often serve to increase state power (Ferguson 1990), especially through the creation of infrastructure that facilitates the process of project implementation, such as roads and government or development authority offices (Braun and McLees 2012). While much of the literature focuses on the many development projects that fail to reach their stated goals of integration, employment, or infrastructure development, some projects do succeed or are, at the very least, held up by development authorities as succeeding. The framing of a project as a success, however, can actually serve to hide its side effects and the negative impacts on local people. The "success" of a project could itself justify further expansion of infrastructure or changes in structural power through government intervention and the control and commodification of rural resources, such as water, previously out of reach of capital and the state.

Place, space, resources, and power

The loss of control over resources implicit in these changes in ownership and power, and the invisibility of the social and economic violence of displacement embedded within these processes, are possible because of the way that development authorities and the state view places as empty and abstract spaces in need of productivity (Braun and McLees 2012) - in this case, harnessing the free-flowing water of mountain areas in a process of commodification. These wide, open, 'empty' spaces are seen for their richness of resources but are also seen to be in need of efficient management so that those resources are used to maximum potential (Harvey 2006), which of course marginalizes existing systems of resource allocation that may not be coherent to outsiders (Boelens et al. 2016; Fontein 2008). Development authorities and states rely primarily on the technical fix through a system of planning where every detail of the process is attempted to be rationally understood and controlled (Mitchell 2002; Mosse 2005). As development expertise is increasingly technical and professionalized, development authorities and consultants conceive of the practice of development in the abstract (Mitchell 2002; Mosse 2005), subordinating local knowledge and experience.

The ideological and technocratic project of development, and specifically the implementation of technological fixes to depoliticized problems, remakes societies' relationships to nature and power over time (Braun and McLees 2012). Relationships of and to power, however, are not uncontested, and economic, social and political power is enacted at different scales and can change over time (Smith 2008). Analysis of megaprojects such as large dams, mines, manufacturing zones and tourism have allowed scholars to clearly see the relationships between abstracted processes of development, modernization, and globalization and the social and physical transformations of landscapes (Gellert and Lynch 2004). The analytical tools of political ecology bring greater attention to the material and political dimensions of resources and power, which are shaped by temporal and affective dimensions.

\section{Political ecology, temporality, and anticipation}

Political ecology, a multi-disciplinary approach that addresses concerns of both political economy and cultural ecology, emphasizes how environmental resources and decision-making are material and political, and are affected by different interests, investments, and power (Buechler and Hansen 2015; Peet and Watts 2004). Political ecology considers how environmental resources and struggles are sites for the contestation and reproduction of social differences, and how these social locations and interactions are embedded within broader political and economic processes that are located in place, space, and time. The political, economic, and 
environmental context in which resource extractive development occurs demonstrates the utility of a political ecology framework, and increasingly political ecologists are advancing our understanding of the role of time and temporality.

One dimension of temporality is the multiple timescales operating in resource extraction and how they are mobilized in relation to planning over the course of the project. Long-term construction of extractive infrastructure such as the multi-dam LHWP water scheme often occurs in phases with extensive impacts over time. Phases are often representative of major components of the project - for example, often attached to the main component (in this case, large dam) that will be built during that part of the project. However, each capital "P" Phase also has small "p" phases within it that organize the elements of the project. For example, for Phase 1A, which included the building of Katse and 'Muela Dams, there were periods focused on pre-construction studies, construction of roads and supporting infrastructure, implementation of social programs and compensation plans, and so on. These dimensions within Phases take place over many years and in relation to previous steps and future developments. Even as Phases are considered completed, the consequences from them do not fall neatly into these categories and may endure well past official timelines.

Phases also represent opportunities to make changes in the implementation of the project as it progresses. This may be a function of a change in the consultancies employed by the development authorities to design and carry out the social and compensation policies, for example, or changes in policy by the same consultancy in the evolution of its programs. The changes may also be in response to lessons learned over time, either through internal bureaucratic assessments or through pressure from different stakeholders in the process. Of course, the continuation of the project through the next phase reveals what doesn't change as well (Molle et al. 2009; Mosse 2004 ) - the commitment to a resource extractive approach to development in the region.

Jenkins argues "a regional scale approach to political ecology provides utility as a heuristic to conceptually frame the concepts of governance, resource access, and ecological degradation between larger processes of economic restructuring and more localized micro politics" (2016: 182). Similarly, the social and economic histories of regions shape how national development trajectories are envisioned, and these shared histories can be drawn upon to legitimize project plans in the present (Cross 2015), while marginalizing alternatives (Bromber et al. 2014). These narratives - in this case, development and prosperity through resource extraction - are bound to "local socioeconomic or ecological effects of larger political economic affects" in scalar ways, elucidating how "region in political ecology can be used as a conceptual tool at the borderlands of micropolitical global or national political economic processes to help one arrive at common themes" (Jenkins 2016: 184).

In regard to large dam projects, Bromber et al. (2014: 290) argue that the "contested nature of these projects is often negotiated and managed through a particular politics of temporality" that often involves promotion of those dams through a "politics of promise" (Schayegh 2012). Large dams are invoked as "accelerators of time" (Meyer 1982: 554) as they are a means toward physical, ecological, social, and economic transformations across scales in attempts to solve a host of perceived problems by the state and project proponents. The promises of modernization, irrigation, energy, flood relief, water security, and - in this case revenues for development are offered to rationalize the large investments of capital over other solutions (Bromber et al. 2014). People directly affected by large dams are encouraged to embrace the future imaginary of these promises of development in specific terms, with the anticipation of a better life through the project benefits "not yet" (Weszkalnys 2014) delivered. The anticipation of these future benefits can be productive of new subjectivities (Cross 2015; Weszkalnys 2014), and have temporal and affective dimensions.

Adams et al. argue that anticipation is an "affective state", that is, "not just a reaction, but a way of actively orienting oneself temporally" (Adams et al. 2009: 247, emphasis omitted, quoted in Weszkalnys 2014). Weszkalnys further elaborates the point, noting that, "To anticipate is not simply to expect; it is to realize that something is about to happen and, importantly, to act on that premonition" (2014: 212). Her notion of a "temporal politics of a disaster yet to come", in her case anticipating economic disaster related to natural resource wealth, suggests a type of mutuality between the anticipation of a future with disaster and the demands on the present for "close attentiveness to what the future holds" (Weszkalnys 2014: 213). 
This mutuality of temporality and affect is further explored through the "economy of anticipation" that undergirds the Andhra Pradesh Special Economic Zone (APSEZ), one example of India's contemporary largescale industrial infrastructure projects (Cross 2015). Economic zones like APSEZ are "deeply affective spaces" (Cross 2015: 425), which not only reflect the dreams of investors and speculators, but "encourage dreams of profit and improvement among those who are set to be most affected by their construction, creating arenas in which diverse modes of speculation are brought into generative engagement" (p. 426), even if not always allied, without conflict, or if highly unequal. The promises of these future possibilities for a better life are not inherently persuasive or credible, Cross argues, but were convincing because they "invoked local registers of aspiration and tap into vernacular dreams for social and material transformation that are assembled from globally circulating media forms and out of local social histories" (2015: 429). The economy of anticipation both reflects and constitutes the aspirations of ordinary people which are then entangled with the plans and promises of future benefits that are actively promoted and encouraged by local project workers, development authorities, and government officials.

In efforts to implement large-scale initiatives, project investors and authorities tend to minimize costs and amplify proposed benefits, rationalizing the re-organization of resources and space through the contemporary implementation of technocratic solutions for the imaginary of future revenues and development. These projects, of course, take place in specific place and over time, in the landscapes and communities which absorb the most direct consequences of the social and environmental changes that result, including processes of resettlement and dispossession (Perreault 2013; Rousselin 2018). The affective and temporal dimensions of these large dam infrastructural projects have been less developed, but as Bromber et al. note, large dam projects are an:

excellent site to study the ways in which 'experience' and 'expectations' are interrelated in the 'present' by conceptualizing and permanently re-working the future. The 'politics of promise' as well as the 'politics of threat' associated with many dam building projects articulate a particular temporal approach; a political and economic orientation towards the future, associated with expectations of a 'better life.' But the ways in which these expectations and conceptions of a 'better future' are framed vary according to regional and historical context (2014: 295).

This article builds on and extends this literature and my previous work to further develop temporal and affective dimensions in our understanding of large-scale dams as resource extractive projects that are both located in space and time, and in the social histories and experiences of people directly affected. In the sections below I focus particularly on the economy of anticipation among ordinary people directly affected by the LHWP, and do not fully address the important work of activists and organizations in Lesotho, South Africa, and internationally who organized resistance to the project at particular times in creative and significant ways. I have addressed these elsewhere (Braun 2008; Braun and Dreiling 2014), as have others, and these fall outside the scope of this article (see Bond 2002; Letsie and Bond 2010; Thamae and Pottinger 2006; and the comprehensive work of International Rivers).

\section{Research context}

Lesotho is a small, mountainous, landlocked country surrounded by South Africa on all borders (see Figure 1). With a population of approximately two million people, over 80 percent of Basotho, people of Sotho origin, live in rural areas using gendered livelihood strategies that rely on agriculture, livestock farming, wage labor, and informal economic activities (Epprecht 2000). Historically, Lesotho conforms to a classic model of a dual economy, with a primary subsistence sector in the rural regions of the country and a secondary migratory labor reserve economy dependent on South Africa's mining and industrial sector. Male migration to South African mines peaked in the late 1970s and 1980s when up to 35 percent of active wage earning men from 
Lesotho were working in South Africa (Central Intelligence Agency (CIA) 2010), often making women de facto heads of household. ${ }^{2}$

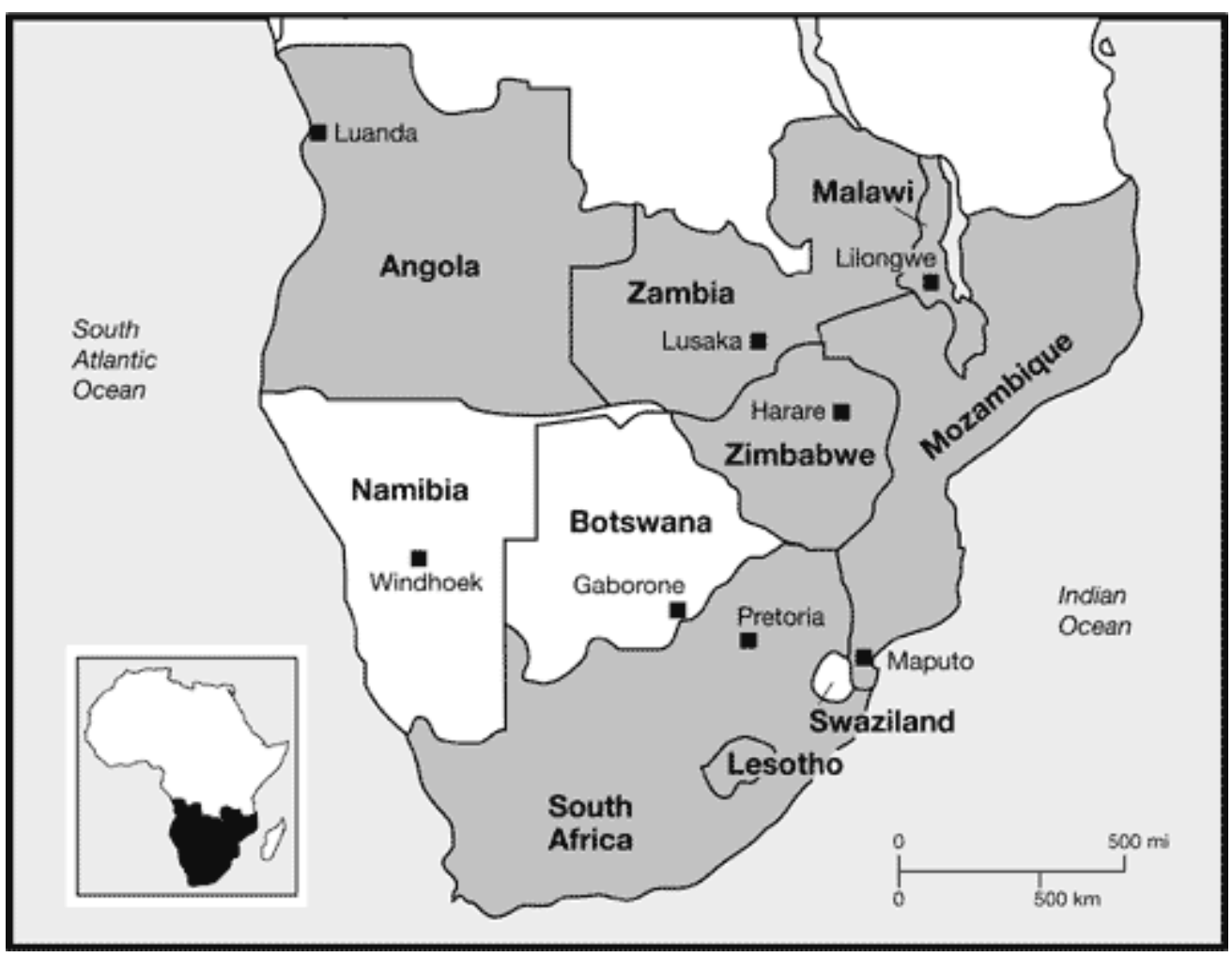

Figure 1. Map of Southern Africa. Source: Christian Aid (2005).

With the dramatic retrenchment of male miners since the early 1990s (Global Policy Network 2006), migration for work in the South African mines has not been an option for many men from poorer, rural areas such as those affected by the LHWP. Local opportunities for wage labor in these extremely remote highlands areas remain very limited, and most wage labor still involves migration to South Africa or to urban areas in Lesotho. Increasingly women are migrating to urban areas to find work in the highly competitive domestic service field and the textile and garment industry. Estimates indicate up to 50,000 Basotho were employed in textile and garment factories during the peak of employment in the early 2000s but jobs in these foreign-owned factories have greatly diminished since 2004 (Bennett 2006). These historical and contemporary migration patterns, a direct result of persistently high rates of poverty and unemployment - approximately 60 percent $^{3}$ (World Bank 2010) and 30-40 percent over the last two decades, respectively (United Nations 2007) —as well as structural relations of inequality regionally and globally, have also proven to be major factors in the spread of both HIV and STIs during this period. In 2007, the HIV/AIDS prevalence rate was $23.2 \%$ among adults in Lesotho, the third highest in the world (United Nations 2007).

\footnotetext{
${ }^{2}$ Historically this has been referred to as "oscillating male migration" (Murray 1981). It refers to the cyclical movement of migrant Basotho male miners to South African mines for eight to eleven months of the year and their return to Lesotho for the remaining months of the year.

${ }^{3} \mathrm{~A} 2010$ World Bank evaluation of the LHWP reports that "the distribution of Lesotho's income is one of the most unequal in Africa. Some 60 percent of the population are poor, and a third are in extreme poverty. The poverty incidence is 72 percent in rural areas compared with 27 percent in Maseru, the capital" (p. 2).
} 


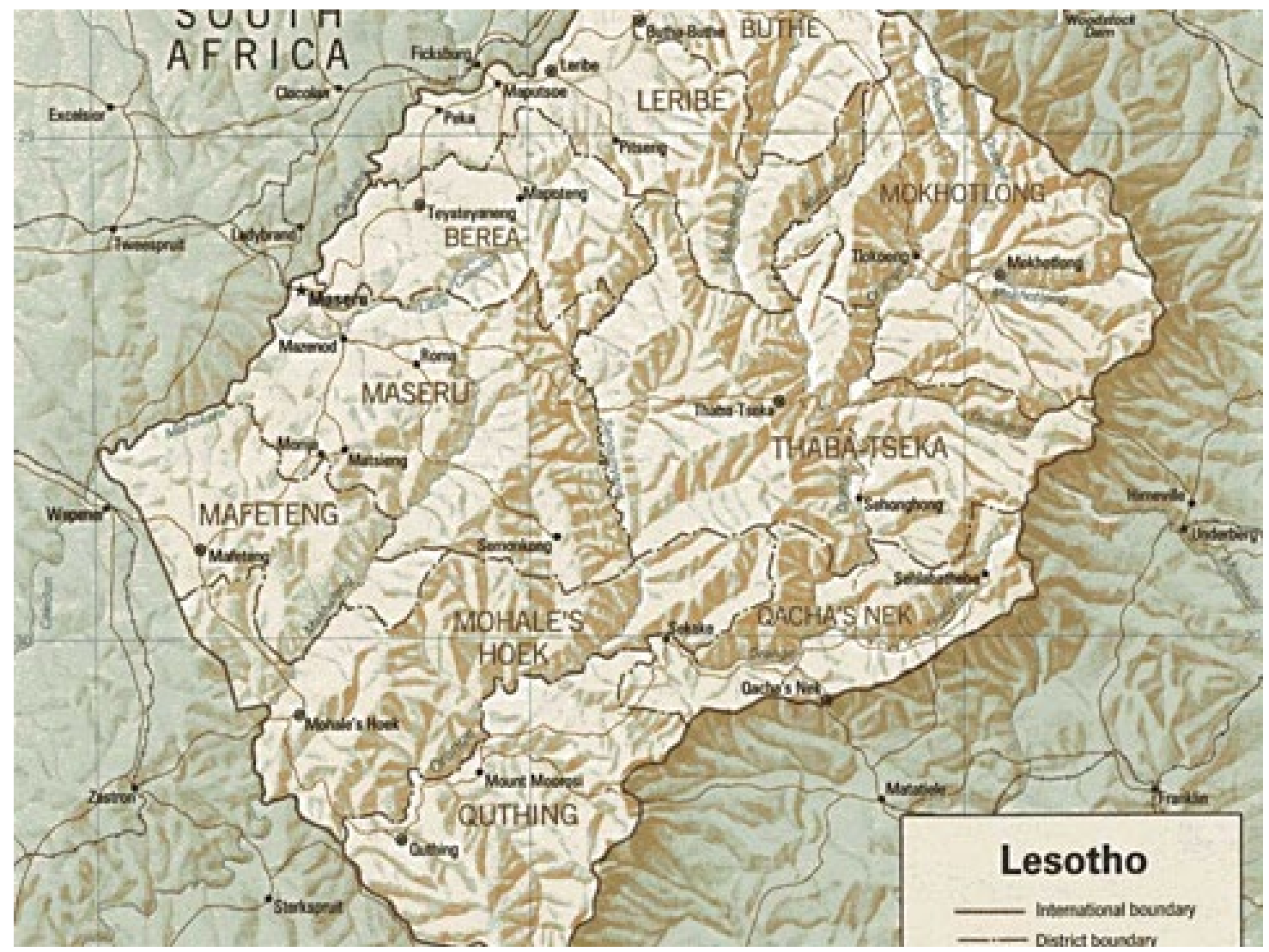

Figure 2. Map of Lesotho.

Deemed perpetually poor in international development circles in the early to mid-1980s (Ferguson 1990), the Government of Lesotho no doubt allowed the development priorities of international agencies, particularly the World Bank, to overshadow other priorities, in addition to the pressures of its politically and economically dominant neighbor, South Africa. At the time, the rise of a neoliberal vision of markets and of development initiated a wave of structural adjustment policies by the International Monetary Fund (IMF) and national and regional development agendas that stressed export-oriented and resource extractive development models, approaches which had a long history in the region. In Lesotho, this neoliberal, export-oriented vision was articulated as marketing "white gold", or the extraction and sale of water to South Africa through the transnational water delivery scheme, the LHWP.

The LHWP is a multi-dam infrastructural and development project being undertaken by the governments of Lesotho and South Africa and is considered the most complex water scheme in Africa (Davidsen 2006). Based on a treaty signed in 1986, the US $\$ 8$ billion project is funded in part by the World Bank, the African Development Bank, the European Investment Bank, and several European funding agencies, and is being implemented by the parastatal Lesotho Highlands Development Authority (LHDA) in Lesotho and the Trans Caledon Tunnel Authority (TCTA) in South Africa, with the whole project overseen by the Lesotho Highlands Water Commission (formerly the Joint Permanent Technical Commission). The water delivery scheme was designed to include five dams linked to cross-national tunnels constructed in four phases, with the primary purpose to capture, transfer, and sell water from the rural Maluti Mountains of Lesotho to the Gauteng region of South Africa, as a means of generating national revenues for development in Lesotho (Lesotho Highlands 
Development Authority (LHDA) 1986). ${ }^{4}$ Three dams have been completed, Katse, 'Muela (the hydropower station), and Mohale, as part of Phase 1A and 1B, completed in 1998 and 2002 respectively.

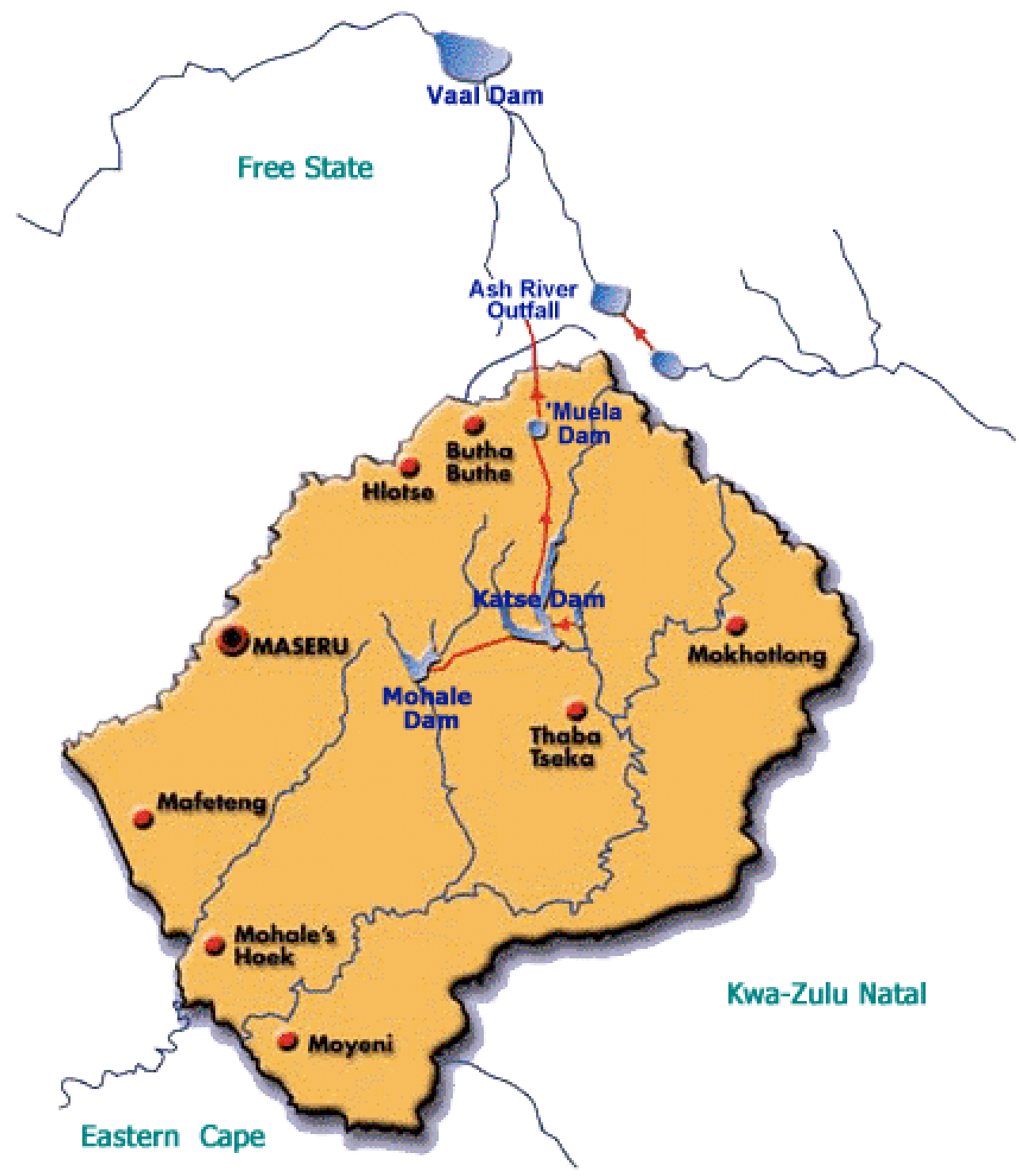

Figure 3. Map of Phase 1A and 1B, Lesotho Highlands Water Project (LHWP). Source: Lesotho Highlands Development Authority.

Based on the treaty, subsequent phases had to be negotiated, and the agreement for Phase 2 was formalized in 2011. The delay between the two phases largely reflected concerns about inadequate compensation raised by both civil society and institutional actors and highly publicized corruption in Phase 1.

\footnotetext{
${ }^{4}$ South Africa was anticipated to pay approximately US\$55 million in royalties to Lesotho each year. In 2002, reports indicated that Lesotho had received about US\$18 million in average annual revenues due to less than estimated amounts of water (Hassan 2002). As of 2006, the World Bank reported cumulative royalties were 1.9 billion Maloti or US\$240 million, which is slightly above projections upon initial appraisal (2010: 10). They also note these royalties have not been used toward the stated goal of poverty alleviation (World Bank 2010: 9).
} 
There was also less water than anticipated, leading to fewer royalties for Lesotho and continued problems of scarcity, inequities, and skyrocketing prices for water in South Africa (Bond and Ndlovu 2010). Despite these issues, at the inauguration of Phase 1 at Mohale Dam in 2004, King Letsie III "spoke with great anticipation" (Matli 2004: 19) as he announced the two countries had agreed to proceed with feasibility studies for Phase 2. South African President Thabo Mbeki cautiously agreed, while noting, "...there is no doubt that together we have to take into consideration a number of factors before proceeding with new phases" (Matli 2004: 20). In October 2016, Lesotho's Water and Sanitation Minister Nomvula Mokonyane noted further delays had extended the timeline of the overall project, including unrest following multiple national elections since 2012 and the necessity of getting the incoming government to "buy in" on the relevant treaties, protocols and policies, particularly those that are new to Phase 2. According to Mokonyane, "We don't want to be seen as dominating the Basotho but be equal. The plan on Phase II is to invest in inclusive growth for Lesotho and South Africa" (Infrastructure News 2016: 1).

Phase 2 is now currently underway and includes plans to build the Polihali Dam and transfer tunnel system to connect with Phase 1 infrastructure at Katse to increase the water transferred and sold to South Africa. The Phase 2 plans for hydropower generation for electricity within Lesotho are unspecified as they await the conclusion of joint feasibility studies, but the LHDA anticipates water delivery will begin in 2025 .

\section{Social and environmental consequences}

Losses from and consequences of the LHWP's Phase 1A and 1B affected an extensive geographical area in Lesotho, with concentrated effects in communities around the dams, arable and grazing land submerged in reservoirs, and associated infrastructure such as tunnels and roads. At least 20,500 residents of over 120 villages in the project areas of the Maluti Mountains (Phase 1A) were affected by the LHWP (Sechaba Consultants 1994; Tshabalala and Turner 1989), with the Mohale Dam resettling over 400 households and affecting at least an additional 1700 people. Households reported losing important material, social, cultural, and environmental resources such as agricultural, grazing, and garden lands; access to water sources for drinking, household, and agricultural use; forests for fuel wood; river basins for soils, rocks, and grasses used in constructing houses and cultural displays, such as painting designs on houses; and wild herbs and vegetables for food and medicinal purposes, and in some cases resettlement (Braun 2015). Consistent with the social and environmental consequences of other large dams (Scudder 2006), these losses generally burdened already poor Basotho households and created especially intense pressures on women (Braun 2005a, 2005b). The highlands areas chosen as dam construction sites for Phase 1 contain some of the most remote communities within Lesotho, with some of the highest rates of unemployment and destitution (Sechaba Consultants 1994; Tshabalala and Turner 1989). At the beginning of the LHWP, 60 percent of households in the Katse and 'Muela areas - Phase $1 \mathrm{~A}$ - fell below the average income for each area and were considered "very poor" (Panel of Environmental Experts 1991: 25; Tshabalala and Turner 1989: 9).

The social changes were also dramatic in the areas near the Phase 1A dam sites, as these remote communities absorbed an influx of mostly foreign workers to design, build, and run the dam and all its supporting infrastructure. In the case of Katse, the most remote dam area, most of these workers were foreign white men, traveling alone, who were relocated to this remote setting to work on the LHWP for a period of years. The conjunction of poverty, with additional stress on or loss of livelihoods, and a large influx of foreign workers, created conditions that facilitated a heightened informal economy among poorer local women to provide domestic service work and sex work (Braun 2011a, 2011b).

The impacted communities are also some of the poorest people in Lesotho, one of the poorest countries in the world, and, ironically, they absorb much of the indirect costs of this form of development. The impacts were also felt in South Africa, as demand side questions were raised about the impacts on low income residents who were experiencing rising water prices, among other effects, due to the cost of the LHWP (Letsie and Bond 2010). Local organizations such as Transformation Resource Centre and the Highlands Church Action Group worked closely with people affected by the LHWP, including community-based organizations (CBOs) such as Survivors of Lesotho Dams, and with other NGOs based in Lesotho, South Africa, and internationally, such as International Rivers, to organize and raise challenges to the project over time (Braun 2008; Braun and Dreiling 
2014). While much of this organized resistance falls outside the scope of this article, it is worth noting one early challenge to stop the project after Phase 1A.

Three activist leaders from the Alexandra township raised an Inspection Challenge to the World Bank and its Panel of Environmental Experts, as well as the municipal and national governments of South Africa and Lesotho in 1997-1998 (Letsie and Bond 2010). Their challenge raised a number of concerns regarding the social and environmental costs and implementation problems in Phase 1A in both South Africa and Lesotho. In South Africa, they argued that low-income residents in townships such as Alexandra were enduring the costs for the LHWP mega-project through rising consumer water prices, fiscal strain on municipalities and increased water cut-offs, and fewer resources to build water infrastructure for low-income communities. Their challenge called for canceling Phase 1B and future phases of the project which they feared would only worsen the described impacts, and was endorsed by several South African NGOs. Some organizations in Lesotho, such as the Highlands Church Action Group, were also working internationally with South African NGOs and international organizations such as International Rivers, but the Council of Lesotho NGOs endorsed Phase 1B in early 1998 (Letsie and Bond 2010: 61). These challenges in South Africa were incredibly important in raising questions about the impacts and costs of the LHWP in both countries, including demand-side questioning of the water transfers to the Johannesburg region. They also built visibility and civil society connections transnationally, and applied pressure on the World Bank and the two governments, but ultimately were dismissed by the Panel of Environmental Experts (see Bond and Ndlovu 2010; Letsie and Bond 2010).

The LHWP also gained notoriety for being the world's highest profile case of corruption, when the top LHDA official, Chief Executive Masupha Sole, was convicted in a criminal trial for taking R5-million (US\$300,000) in kickbacks between the late 1980s and early 1990s from Canada's Acres International and German-based Lahmeyer International, both engineering consulting firms which had "received lucrative tenders as consultants on the construction of the Katse Dam" (Infrastructure News 2012: 1). Both firms were also convicted and fined by the Lesotho High Court, and were ultimately debarred from the World Bank after international pressure (Bond and Ndlovu 2010). Other government officials were also convicted of corruption for taking bribes and enriching themselves with project monies. Sole was sentenced to 15 years but was paroled in May 2012 after nine years in jail. Three months later Sole was appointed as a technical adviser to the Lesotho Highlands Water Commission, the entity that has equal representation from both countries overseeing the project, despite objections from within Lesotho and South Africa. Critics were further concerned that his appointment occurred "at a time when South Africa has approved an investment of more than R9-billion in the construction of the Polihali Dam to supply more water to Gauteng" (Infrastructure News 2012: 1).

\section{Method and methodology}

This article draws from multi-site ethnographic fieldwork conducted in Lesotho in 1997 and 2000-2002 in all three active dam areas, and ongoing documentary analysis research. Periods of fieldwork included participant observation, formal and informal interviews, and documentary research. As a white, American graduate student in 1997, I started this research as a volunteer with a small NGO in Lesotho. My colleagues there were incredibly generous in guiding me in so many ways and as translators. This collaboration continued into subsequent fieldwork experiences, where I later had a Fulbright affiliation with the National University of Lesotho. With help from colleagues at all these entities, I hired and trained research teams to help with surveys and interviews of households directly affected by the LHWP, attended relevant meetings and conferences, and interviewed development consultants and officials during my fieldwork.

Living in the communities directly affected by Phase 1A and Phase 1B of the LHWP, I conducted countless informal interviews with people living proximate to the project as part of our everyday interactions as neighbors, friends, and acquaintances. Informal interviews were recorded in field notes. With my research team, over 300 formal interviews were conducted in 45 villages affected by the LHWP and were semi-structured and open-ended. Interviews were designed to ask participants a similar set of questions while affording them the opportunity to elaborate and introduce new topics and ideas. Most interviews were conducted in the highlands areas, with a few in resettlement sites in urban areas, and ranged from 15 minutes to one and a half hours. Interviews were conducted in both Sesotho and English, and I always had a local translator present to 
ensure proper translation due to my limited language training. Interviews were recorded when possible, and then transcribed and translated into English as needed. Formal interviews are summarized by dam location and fieldwork period in Table 1.

\begin{tabular}{|l|c|c|c|}
\hline Location & $\mathbf{1 9 9 7}$ & $\mathbf{2 0 0 0 - 2 0 0 2}$ & Total \\
\hline Katse & 16 & 94 & 110 \\
\hline Muela & 13 & 76 & 89 \\
\hline Mohale & 0 & 93 & 93 \\
\hline $\begin{array}{l}\text { Total formal household } \\
\text { interviews }\end{array}$ & 29 & 263 & 292 \\
\hline
\end{tabular}

Table 1: List of formal interviews by dam location, 1997 and 2000-2002.

A consistent theme in my interviews and conversations with people living in the LHWP affected areas had to do with the challenges of poverty, and the hope that the project would bring greater ease and prosperity in an area with very limited employment opportunities. In 1996, when Phase 1A was in construction, the average yearly income for a Basotho household was US\$440 (Pottinger 1996) and was likely much lower in the highlands communities proximate to the Katse and 'Muela Dams. Over 50 percent of the total population lived below the international poverty line of less than US\$1.25 a day.

These national statistics give a sense of conditions at the village level, although village level data are not available. Ethnographic data, reinforced by national and international information, suggest that while conditions within villages vary, remote highlands communities in the Katse Dam area generally share in common extreme poverty, the absence of modern social infrastructure such as electricity, running water, and plumbing, and have limited paved roads. For example, I lived in the village of Khokhoba for extended periods during research trips due to its proximity to the Katse Dam and related facilities. These villages proximate to Katse Dam absorbed direct losses of agricultural and grazing lands to the LHWP, fields that were means of production vital to the livelihood strategies of most families and households in these communities. Indeed, most of the facilities for the development authorities' field offices and the housing and stores for foreign consultants were built on lands the LHDA appropriated from residents of Khokhoba and, to a lesser extent, its neighboring village of Makhoabeng. These new structures had electricity and other amenities, while local communities remained without electrification and unable to access these services as they negotiated living with no, or reduced access to, agricultural fields and grazing lands.

Like other villages in the area, Khokhoba and Makhoabeng are largely organized around a subsistenceoriented agricultural economy paired with migratory wage labor employment, reflecting the expectations from existing literature about adult men's and women's roles in labor markets across the region. In my formal interviews, one-third of respondents reported no formal education while four participants (1.5 percent) reported higher education, with one of them living in the Katse area. Participants in the Katse area overwhelmingly declared farming, mining, and looking for work as men's primary occupations and household work and farming as women's primary occupations, paralleling what is reflected in the literature. Reflecting on the very limited opportunities available for formal employment in the highlands area, interviewees reported casual labor or piece jobs, looking for work, or none as the secondary occupations for themselves and other adults in their households and declared their hopes, often unfulfilled, for work with the LHWP.

Building from the aforementioned literature and the empirical evidence, I employ a narrative approach in presenting these data in the analysis below. All interviewees' names are pseudonyms.

\section{Temporality and the economy of anticipation: resource extraction, displacement, and dispossession in large dam building in Lesotho}

In the late 1980s and early 1990s, the Government of Lesotho's and the Lesotho Highlands Development Authority's assurances of the benefits of the LHWP were generally taken to heart in the largely poor communities of the rural highlands where the bulk of the construction in the first phase of the LHWP was to 
take place (Phase 1A, Katse and 'Muela Dams). The promises of prosperity through "white gold" was a story with great appeal to these hardworking farming families: Lesotho would be able to sell their abundant, freeflowing resource of water to South Africa, where water was in high demand, to generate revenues to fuel modernization and development, including the generation of electricity and jobs that would make their lives easier and better. The idea of water as "gold" that was freely available was incredibly enticing.

Amidst the plans and blueprints, the concrete and metal, the LHWP mega-project was persistently buoyed by the ever-present discursive connections made by project officials to the affective and material aspirations of highlands residents for a better future. From the start of the LHWP, lower level project officials informed residents - often at lipitso, community gatherings (Kenworthy 2017) - of the future benefits of the project for Lesotho and how it would bring development and a better life to these poor communities. As most of the impacts of the LHWP would occur in these highlands areas, households to be resettled were told of new and improved homes, and those affected by losses of fields were promised due compensation. The local pain, so to speak, would be for the larger national gain from which they would all benefit - the anticipation of development for the farmers and the rural poor, and prosperity for Lesotho.

In contemporaneous interviews in 1997 and between 2000-2002, residents recounted stories about the future benefits that development officials described, which included the building of roads, schools, health clinics, water taps, and electricity, and the proliferation of opportunities for employment and of tourists to buy their goods and services. Residents were told there would be schools and health clinics within reasonable distance, a welcome change in rural areas where children may walk miles to the nearest school, or the ill may have to weigh the cost of transportation to get to a clinic, or simply not go due to the distance or cost. The possibility of these kinds of opportunities to access education and health care which were often out of reach for many in these communities, particularly the poorest households, were understandably alluring and desirable.

The promises of the LHWP were fueled by an "economy of anticipation" (Cross 2015: 425), the hopes and aspirations of modernity, which relied on the entanglement of the affective currency of poor people's dreams and the capital of transnational investors who together, in their own ways, imagined a future in which this water scheme could bring development to a place long perceived as persistently poor. This symbolic economy of hope and desire is captured through different narratives which are at work within and across the project, and which, I argue, help explain its persistence over time including through significant political changes in both countries. The building of roads as part of Phase 1A was arguably the foundation on which these dreams and aspirations were cultivated.

\section{Roads and advance infrastructure}

Prior to construction, the planned dam sites experienced a period of disinvestment in the project areas by the state as planners anticipated large-scale changes since at least the early 1980s (Scudder 2006). The construction phases for large dams are typically long due to the size and scope of the engineering plans, and extractive projects that involve large-scale transfers of water which require more planning and extensive construction over time, often including a period of construction for "advance infrastructure" that is necessary before the main parts of the project can be built. In Lesotho, the remoteness of the planned site for the first dam (Katse Dam) in the highlands of Thaba-Tseka necessitated the building of roads through mountains that reached above 11,000 feet. The dynamite, boring machines, and large trucks used to build new roads through these largely inaccessible mountains brought both the challenges of construction and the promises of ease and access to these remote communities.

The roads are, perhaps, the through-line between all of the realized benefits and imagined hopes of the LHWP. The stories of new and improved roads beckoned to a future less isolated, with greater ease of mobility and access to commercial centers that currently required large investments of time and money for travel, resources that were scarce for most households in these mountain communities.

The roads themselves became important symbols of the larger stakes involved in large-scale infrastructure development like the LHWP. The lucrative royalties anticipated from the extraction and sale of fresh, seemingly abundant water flowing through Lesotho's mountains, must first be achieved through the slow process of building basic paved infrastructure that would allow the movement of the machines into the remote site planned for the dams and reservoirs. The lack of roads demonstrated the need for development in rural 
Lesotho; at the same time, the roads being created only in the course of the LHWP demonstrated how development was oriented towards national, large-scale efforts and not calibrated to the direct needs of local communities.

Households and villages proximate to these new roads and tunnels absorbed the noisy, smelly, disruptive years of construction for the supporting infrastructure for the LHWP. The highlands areas often required controlled dynamite explosions to shape the mountains in anticipation of the many vehicles that were to travel the future roads paved on their sides, or for the tunnels that were the connecting infrastructure to support the engineered extraction and transfer of water. The building of the roads also created impacts that were not anticipated, such as houses and walls cracked by the blasting of dynamite or fields damaged by the construction. People with property negatively affected by the building of the roads made claims to the LHDA, but often struggled to get a response let alone compensation for their damage (Thamae and Pottinger 2006). As noted by some of my interviewees, many of these households went without compensation for years even as local community organizations, such as the Highlands Church Action Group and the Transformation Resource Centre, advocated on their behalf and had material evidence in support of their claims. Indeed, those who expectedly lost agricultural fields to the LHWP sometimes also struggled with getting their due compensation (Panel of Environmental Experts 1991; Thamae and Pottinger 2006).

Even with the significant grievances about compensation, the early years of Phase 1A were largely still hopeful times; the roads were generally anticipated with excitement and pleasure despite the disturbances. Where the disturbances were acutely felt, however, the frustration and anger of particular circumstances - fields being damaged or walls being cracked, for example - were seen as problems of implementation, not a complaint about the decision to build roads or even the LHWP. The LHWP was broadly supported by folks in the highlands areas in the beginning because development was generally understood as desirable, as a means to realize everyday aspirations for a better life. It was also hinged to a hopeful sense that this signaled a new era of economic and political subjectivity (Cross 2015), whereby the state's investment in the LHWP was an investment in them, in their communities, even if it was still unclear how those affected would directly benefit. At least that was true in the early years of the project.

After construction of Phase 1A, the roads were the single most demonstrable achievement of the project and the improvement most welcome by local residents. That these roads were only built when needed to facilitate the progress of the LHWP, and not built years prior as politicians had promised many times before, was not lost on many highlands residents. "At least the project has finally brought the roads", was a common refrain in my interviews, signaling the symbolic meaning of roads "finally" being approved by decision-makers in the capital, Maseru, who were perceived as never prioritizing the development that mattered in their lives. "At least" simultaneously acknowledged the disappointment of what else the project did, or did not, bring amidst the welcome road infrastructure.

Serious social issues related to the road and its increased activity began to surface in Phase 1A. South African Water Minister Kader Asmal acknowledged some issues, saying, "Social problems such as increased alcohol abuse, increased sexually transmitted disease and increased stock theft have all been reported in villages along the new Katse Road", but then Asmal pivoted to a narrative of anticipation, stating in part:

These negative impacts must be weighted against the benefits arising from the project including access to improved health and educational facilities, water supply to communities, sanitation at schools, and, at villages close to the sites, the construction of community halls, community offices, creches, open markets, and road access. One must also weigh in the benefit of employment opportunities for local people, both in the construction phase and in the considerable long-term maintenance tasks (Asmal quoted in Bond 2002: 141).

As Asmal acknowledges issues, he also draws back to the economy of anticipation, simultaneously dismissing complaints as he points to the anticipated benefits "arising from the project" and nods to the opportunities of the future in the "considerable long-term maintenance tasks" associated with Katse Dam. As Bond notes, the few improvements made - such as 157 latrines in eight schools, seven villages getting trenches 
for water supplies, and feeder roads - were "relatively small consolation when considered in the context of the US\$2.5 billion cost of the Katse Dam" (2002: 141).

Over time, more people had experiences or heard of others' experiences of broken promises in Phase 1. How the project was being managed, including rumors about corruption which later proved accurate, and how affected people were treated - particularly in contrast with the foreign workers - increasingly became issues that eroded the faith and trust that had previously undergirded the hope that their aspirations for a better life would manifest through the LHWP. 'Mathato Marumo, a farmer and mother of three in Khokhoba, situated her growing frustration about compensation within a larger critique of the positionality of affected people and the implementation of the LHWP:

How is it [the development authorities] make electricity for these foreigners, make them these nice homes, and yet we still live like this? No water, no toilet, no electricity, no job. Ach, I cannot even get fair compensation for my fields, things they have taken from me, they say my field was not as big as it was. They say I do not know how big my field was. How can I not know my own child?

Larger questions about who was benefitting from the project, such as ones 'Mathato raises, became more common and critical, and this was most evident in relation to the hopeful expectations for employment and business opportunities during and after the construction periods in Phase 1 $\mathrm{A}$, and in relation to resettlement in Phase 1B.

\section{Employment and business opportunities}

As affected communities negotiated the influx of foreign and regional Basotho migrants to the dam construction areas, the confluence of retrenchment from South African mines and losses of agricultural fields a significant means of production - to the LHWP added considerable economic pressure on rural highlands households to find alternate means of livelihoods. In this context, the promises of employment prior to the construction of the LHWP and the anticipation of an improved economy for tourism and business opportunities were especially important to local residents.

In Phase 1A and 1B, in contrast to the hopes of local residents, employment opportunities were limited during the boom of the construction phases (Braun 2011a, 2011b). Official explanations emphasized the lack of capacity in local communities for the kinds of skills that were required for positions with the LHWP. Employment opportunities, as I have analyzed elsewhere (Braun 2011b), were largely stratified by gender, race, and global status, with local men largely accessing less secure casual day laborer work and women having to rely on informal opportunities. At Katse Dam, development officials assured them there would be numerous secondary opportunities to make money through selling goods and services to the largely foreign workforce and from the increased tourism that would result from the building of the dams, roads, and a hotel, Katse Lodge, as part of the LHWP.

Hopes to access the development monies, then, largely rested on capturing the economic boom from the ancillary opportunities around the project areas. These hopes crystallized around a new lodge and improved bus and taxi stop near Katse Dam which they were told would bring tourists and money, creating opportunities for jobs and businesses, such as owning a taxi to drive people to the larger Butha-Buthe town or the capital, Maseru. The new concrete taxi station had a handful of open market spaces for vendors, as noted by Asmal above, each one an open-air window with a shelf for them to greet their customers amidst the ample parking for taxis and buses. A few vendors took on this space to sell breads, fruits, and snacks to travelers or those hanging around. Business was uneven at best, and some vendors took to shifts to catch the busy times and then move on to other places or other work.

Early one morning I walked down the road to the new station. I bought a steam bread wrapped in newspaper from a vendor named 'Matheko and I asked her about her experience selling there. She laughed, saying, "It is good! It is very nice. But it is cold, the concrete is cold and that is not good for my bread. I have to keep just a little bit here and my daughter brings me more bit by bit." As she mentioned this, her daughter, a shy girl around 12, popped around the corner with a plastic bag filled with warm, newspaper-wrapped breads. 
'Matheko said, "See? She is bringing me bread to sell, I can't cook here and it is so cold", as she turned to take the bag from her daughter. As she instructed her daughter, I looked around the bus stop to see there were only a handful of people there and no buses or taxis. I asked 'Matheko about this, and she laughed again before saying, "Yes, it is true! You see there are not so many people here. Ach, it is a real problem. I will only stay here maybe one more hour and then I will go. I will go tend to the field, I have no one to buy [my bread]." When I asked her about the large number of project workers that moved to the highlands to build Katse Dam, she shook her head. "No, these people do not come here. They have their own vehicles so they do not come to take the bus or the taxi. You see them drive by, but they do not buy from us."

Other vendors, often women who could not find formal work with the LHWP, described the disjuncture between the anticipated increased market for their goods and the reality of a largely foreign workforce who did not tend to buy local foods. One woman, who wanted to be called by her English name Sheila, described the issue this way: "These people have their own food. They do not buy ours, maybe some little fruit here but that is it. They have money, but we do not see it. They take a woman to cook for them in the house and they go to the restaurant, maybe. As for us selling [informally], no, they don't buy from us." Sheila points to how the workers from other countries who live in the suburban village for LHDA employees have money and amenities - such as vehicles and homes with hired domestic help - that allow them to travel to get the foods and services they want, which are generally not those offered by informal sellers like her. She also reveals how the anticipated secondary benefits of the investments in the LHWP, such as the promises of work opportunities and increased business activity from the construction phases of the dams, do not necessarily trickle down to local people, particularly those who cannot access some type of formal opportunity with the project or who don't make a personal connection with a foreign worker to secure work as a domestic servant in their homes or for sex work. These strategies to access the benefits of development were notably gendered and classed, with the less well-resourced under more pressure to seek out these opportunities (Braun 2011b).

Resettlement and dispossession further amplified the stress and anxiety of past and impending changes from the LHWP. Villagers were nervous and anxious about the changes ahead, uncertain about when and how the process of resettlement would affect their lives as timelines were often unclear, leaving people waiting and anticipating relocation for years in some cases (Thamae and Pottinger 2006). Some considered refusing to move, the stress of leaving the familiar too much to imagine. Others named the injustice of the large dams displacing poor communities, and their loss of fields and livelihoods. A common theme in Mohale was the experiences of the communities affected by the Katse Dam over time, starting from disturbances from the advance infrastructure in the dam site areas, through the tumultuous years of the construction phase, and the realities of what people perceived as broken promises post-construction and post-resettlement.

\section{Facing displacement and dispossession}

As communities negotiated the above conditions in the context of Phase 1A, households waiting to be resettled in the Mohale Dam area as part of Phase 1B negotiated the anticipation of construction and submersion of their village and homes in the future reservoir (Thamae and Pottinger 2006). They tracked the experiences of those affected during Phase 1A and the early phases of Phase 1B carefully, unclear whether and how they will benefit from LHWP development, whether they will gain access to electricity or improvements from the revenues from the sale of water, or even what their new homes would be like. There were multiple stages for resettlement in Mohale based on the location of households in relation to the timing of the construction and filling of the reservoir (Thamae and Pottinger 2006). The second stage of resettlement in Mohale allowed those households to both witness the moving of their neighbors, and to wait in anticipation of their relocation. On my way to conduct interviews in the village of Ha Matebeleng, which had been given notice of future resettlement due to Mohale Dam, I walked past homes whose families had already been resettled, the empty mud and stone houses standing with roofs toppled to dissuade those relocated from returning. These shells of the former community stood as a constant visual reminder of the impending and uncertain destruction of their own homes and community that was embedded in the promise of improved and modern houses once resettled.

For most waiting to be resettled, they had not seen where their neighbors went or the homes into which they moved. A local organization, Sesotho Media, filmed interviews with people who were resettled in newly built homes within new or host villages during the first stage of Phase 1B resettlement. Sesotho Media organized 
viewings of the film in communities facing resettlement in the future. The film showed the new houses built by the LHDA, with families talking about their experiences and their frustrations. Many of those interviewed in the film offered their suggestions and warnings to people who were to be resettled, speaking directly into the camera and cautioning them about what was true or not, what to demand before they agree to move, and even, at times, advising them to refuse to move.

I was invited to attend one of the film showings by acquaintances at the Transformation Resource Centre. Early that evening we drove out to the village where the film would be shown in a schoolhouse for the community of Ha Matebeleng. Two white pick-up trucks were parked outside the schoolhouse as four young men connected long cables from the truck batteries to power the projector as there was no electricity in the village. As the images started to slowly focus on the screen, the light from the projection lit up the crowded dark schoolhouse. The light caught the eyes of people huddled together on benches and standing along the walls, waiting with anticipation, apprehension, fear, awe, and skepticism. The children present filled the floor between the seats, cautiously playing and mostly awed by the production of it all: the two extended cab pickup trucks, the car battery powered projection, and the sound and images of the film that began to flicker. As the crowd quieted, the residents of Ha Matebeleng witnessed the resettlement of their neighbors a few short months before as documented by Sesotho Media. For most, if not all present, this was their first glimpse into the result of the resettlement process which they were scheduled to endure in the coming months. Discussion after the film revealed the lack of information community residents had been given by local development officials, and the impact of seeing former neighbors - people they knew, who had credibility in their eyes - showing them the reality of resettlement in contrast with the promises of the LHWP.

With this experience, the residents of Ha Matebeleng, to a certain extent, had an advantage over many other communities resettled prior to them. They had the opportunity to preview the disruption that resettlement is, in all of its facets and stages, and to learn from others' experiences. In my interviews with residents, it was clear they were also faced with difficult choices with that knowledge - for some it was empowering; for others it triggered an increased fear and uncertainty about the future; and for many it was both. The realities presented in the stories of their neighbors in the film, at the very least, challenged their ability to hold onto the future imaginary of prosperity, the images and words of former neighbors contrasting sharply with the promises of development LHDA officials had told them would come true once resettled.

For many watching the film, the experiences of resettlement in the prior phase revealed the legitimacy of their worries about whether they will receive rightful compensation and what their homes and lands will be like when they are forced to move. Temporally, some felt less trusting of the LHDA at this point in the process than communities may have been at the start of Phase $1 \mathrm{~A}$, who were hopeful about this new project and the promises of development, such as prosperity from employment and from the sale of water. Others were empowered by the information they received by seeing and hearing the previous experiences of those resettled in Phase 1A. Even as it was sobering and scary to see the realities of former neighbors' resettlement experiences, some described this process as giving them perspective and resolve for their upcoming interactions with development authorities about their own resettlement in this next phase of the LHWP in their lives.

Despite the challenges and consequences of the first phase of the LHWP, the second phase is currently underway and includes the Polihali Dam and its related infrastructure and developments. This phase is in its early stages, and offers an opportunity to demonstrate the temporal dimensions of the process of implementation I describe above. The fairly recent re-engagement of Phase 2 of the LHWP after a significant delay is justified on the seeming success of the project, according to project authorities, that will only be fully realized with the culmination of the subsequent phase of the project.

The continued commitment to the capital intensive LHWP is structured through a logic of continuity and improvement, and through the strategic mobilization of phases that scaffold both the material and physical dimensions of the project, but also the affective and anticipatory hopes of prosperity that the project represents. In this case, it also reveals how project authorities weave these dimensions - the material and the aspirational - into specific planned changes and improvements to address previous and ongoing concerns as projects progress over time. These planned improvements are reasonable and desirable, and also do the work of trying 
to re-align support for the project through the mobilization of hope and attempt to contain criticism of it until the totality of the phases of the project are complete.

\section{Re-investment in extraction for development}

The second phase of the LWHP was recently "reaffirmed" by the governments of South Africa and Lesotho, a symbol of the ongoing commitment to the expansion of the LHWP after a significant delay in the timeline of the project (Barradas 2018). South African Water and Sanitation Minister Gugile Nkwinti, Lesotho Water Minister Samonyane Ntsekele, and the Lesotho High Commissioner Sello Moloto also expressed support for key changes to the implementation of Phase 2, notably focused on improving the equity of cost-sharing between companies registered in South Africa and Lesotho, and to combat corruption through transparency and competitiveness in bidding and procurement. Other changes addressed additional issues noted in Phase 1, whereby local contractors and sub-contractors did not have opportunities to compete. The implementation of Phase 2 is proposed to empower Lesotho contractors and those from marginalized groups in South Africa, vis a vis multinational contractors and companies. Additionally, a plan to build capacity in Lesotho for small companies to participate in Phase 2 is meant to address the lack of Basotho employment and contracts during Phase 1, and provide opportunities for growth in these sectors via the LHWP.

Development authorities in Lesotho and South Africa suggest that the Phase 2 infrastructural plans will address some of the social impacts identified but not resolved in Phase 1. One of the ongoing impacts in the Katse Dam area is the inability of people in local communities to easily cross the extensive reservoir. The creation of the reservoir separated families and communities from each other with uneven capacity to acquire transportation and to retain these relationships. In Phase 2, plans include building more access and feeder roads around the reservoir to connect affected communities using both pedestrian and light-vehicle bridges, and building two major road bridges over the Polihali reservoir. These future proposals are promising that learning from the past has been incorporated into future plans, but ongoing assessments will be key in determining to what extent they are implemented and how successful they are in practice.

\section{The past informs the future: proposed changes, renewed hope?}

Estimates from the feasibility studies planned Phase 2 to be completed by 2020, but more current timelines from the Project Management Unit at the start of the project in 2013 plan for water delivery to start in 2025. The cost of the completed water transfer component was estimated at R24-billion ( US $\$ 1.5 \mathrm{bn})$ per the December 2017 long-term cost plan. Notably, the project authorities have not yet established the cost of the hydropower component which is proposed to provide domestic electricity in Lesotho.

Like Phase 1, this next phase will require substantial building of infrastructure to prepare for the construction of the dam and project components. This "advance infrastructure" phase is expected to be completed by the time of the main project work starting in 2020 . This early work also requires significant amounts of workers, often including office space and housing over long durations. Some of these project requirements are described this way in Engineering News (Barradas 2018: 1):

Phase II will require extensive infrastructure development before the mobilisation of contractors for the two main water transfer works contracts of the Polihali dam and transfer tunnel. Where possible, the existing infrastructure constructed in Phase I will be used. This includes access roads, power supply, telecommunication systems and camps. Significant additional works contracts will be awarded for the construction of all-weather access roads, a bulk power supply network, telecommunications systems and project housing, as well as labour camps on both ends of the transfer tunnel... A permanent housing development will be established near the Polihali dam and transfer tunnel, which will consist of project offices, and residential and community facilities. 
One of the significant elements of a water transfer project like the LHWP is the tunneling infrastructure for the movement of water between the dam-created reservoirs and ultimately the delivery of water to the Gauteng region of South Africa. Building the tunnels through the mountainous region of highlands Lesotho creates challenging conditions and extensive impacts in surrounding communities as it did in Phase 1. Phase 2 will include tunnels to connect the reservoir at Katse with the reservoir at Polihali. Project authorities plan to use the infrastructure at Katse Dam and in the Matsoku valley for the Polihali-Katse tunnel construction, and to use existing accommodation facilities in Katse for housing the consultants and construction management teams working on Phase 2 operations.

Environmental and social baseline studies were completed in 2013 and 2014, with assessments of socioeconomic, public health, biological, and archaeological and heritage aspects. Environmental and social impact assessments and subsequent management and actions plans are reported as in progress (Barradas 2018).

The timeline of the construction of Phase 2 includes a significant period of time between the baseline studies and the completion of the project which has implications for how impacts and subsequent compensation will be assessed. Additionally, delayed investment in the project area in the anticipation of the construction of Phase 2, particularly after a delay in the project timeline, may render communities affected by the lack of investment for many years prior to the baseline studies. The baseline is likely altered by this significant period, and yet this will be used to measure the impacts of the project and determine mitigations for affected people.

As the continuity of the LHWP itself is structured on a logic of improvement within and between its phases, the promises of prosperity continue to fuel hopes for an imagined better future. Yet, the baseline studies which are to capture the referential point for how the impacts of the project on the communities will be measured and ultimately mitigated, are potentially flawed. These studies are altered based on a temporal mismatch between when the consequences are perceived to start and when they actually begin to affect communities, such as through processes of planning that start shortly after sites for large projects are identified (Scudder 2006). This will affect the measurements of the kinds and amounts of losses or impacts that households endure, and may negatively affect their compensation, as well as the larger assessment of how project authorities perceive their responsibilities to make whole, or even improve, the lives of affected people and communities. Even as project authorities seek to make changes and improvements in specific areas, some of the foundational conditions for how communities experience the consequences of these projects in their lives remain unchanged in the planning and implementation over time.

\section{Conclusion}

Freshwater is, perhaps, the quintessential environmental good-a life-sustaining resource necessary for survival, integral to well-being and livelihoods in the rural agriculturally based communities of highlands Lesotho. Large dams fundamentally alter riverine systems and water resources, creating rapid environmental change in the communities where they are situated. Where large dams form part of an extractive-oriented development plan, such as in the LHWP, water becomes commodified and re-organized in a logic of utilitarian and market-based development solutions that reduce the complex hydrological and ecological systems of this region to "white gold." Local communities are generally not included in the decision-making about large dam placement and construction, yet they largely bear the burdens of the social and environmental consequences.

I attend to the temporality of the local experiences of large dam building as they demonstrate how extractivist approaches to resource development may occur over long stretches of time with accumulating effects, and how project discourses rely on affective dimensions, an economy of anticipation, and a logic of improvement to promote the continuity of the project over time. Understanding the temporal dimension includes attention to dynamics and conditions before, during, and after the construction phases of large dams and the accompanied tunneling systems and advance infrastructure often needed to build these mega-projects. The temporal also locates these dynamics and conditions in place, hinged to the discourses and experiences of the LHWP, and shaping subsequent events in the life of these projects and the communities affected by them.

The renewed Phase 2 to expand the LHWP after a significant delay since Phase 1 completion, demonstrates such a temporal process and the logic of improvement that structures the anticipatory narrative for the strategic mobilization of phases over the course of a project. A logic of continuity and improvement 
structures the continued commitment to the capital-intensive LHWP through the strategic mobilization of phases that scaffold both the material and physical dimensions of the project, but also the affective and anticipatory hopes of prosperity that the project represents. In this case, it also reveals how project authorities weave material and aspirational dimensions into specific planned changes and improvements to address previous and ongoing concerns as projects progress over time. These planned improvements, while reasonable and desirable, also do the work of trying to re-align support for the project through the mobilization of hope, and attempting to contain criticism of it until the totality of the phases of the project are complete.

As I consider the social and environmental changes in one large-scale multi-dam infrastructure project, my focus emphasizes how the state creates the conditions that make the present use of natural resources, like submerging lands and selling water, seem rational and sensible and how this take place over time. Understanding this progression requires an approach that can examine temporal changes in large-scale processes of expanding state and market control over natural resources, continuing a re-investment in the material continuation of the project and its persistent narrative of the promise of extractive approaches for national and regional development. This tactic reveals the mechanisms that shift ideas of place and space to recreate rural areas and resources, and consolidate them under state control and make them rational objects of production (Smith 2008). In this case, the strategic mobilization of phases over time allowed reaffirmed commitments to the LHWP and the resource extractive approach to appear renewed through a logic of improvement, even as some fundamental ways impacts would be measured, such as the timing of baseline studies, did not change.

A longitudinal analysis that examines this transformation can reveal the reconceptualization of space over time by looking at it through multiple temporal moments, such as the phases of one multi-dam infrastructure project, and the cycles of consequences that overlap and span its temporal delineations over time. This approach adds complexities to the often taken-for-granted realities that make current uses of space appear ahistorical and 'natural,' revealing how future imaginaries about the anticipatory promises of resource extractive development continue to influence development decisions and practices in the region, despite the material experiences of affected communities in the present.

\section{References}

Barradas, S. 2018. Lesotho Highlands Water Project - Phase II, Lesotho and South Africa. Engineering News [accessed September 7 2019]. http://www.engineeringnews.co.za/print-version/lesotho-highlandswater-project-phase-ii-lesotho-and-south-africa-2018-07-20

Bennett, M. 2006. Lesotho's export textiles \& garment industry. In H. Jauch and R. Traub-Merz (eds.). The future of the textile and clothing industry in Sub-Saharan Africa. Bonn: Friedrich-Ebert-Stiftung.

Boelens, R., J. Hoogesteger, E. Swyngedouw, J. Vos and P. Wester. 2016. Hydrosocial territories: a political ecology perspective. Water International 41(1): 1-14.

Bond, P. (ed.). 2002. Lesotho's water, Johannesburg's thirst: communities, consumers, and mega-damsIn Bond, P. Unsustainable South Africa: environment, development and social protest. Durban: University of KwaZulu-Natal Press.

Bond, P. and M.M. Ndlovu. 2010. Development dilemmas of mega-project electricity and water consumption. In B. Freund and H. Witt (eds.). Development dilemmas in South Africa. Durban: University of KwaZulu-Natal Press.

Borgias, S.L. and Y.A. Braun. 2017. From dams to democracy: framing processes and political opportunities in Chile's Patagonia Without Dams movement. Interface: a Journal for and About Social Movements 9(2): 300-328.

Braun, Y.A. 2005a. Selling the river: gendered experiences of resource extraction and development in Lesotho. Research in Rural Sociology and Development 10: 373-96.

Braun, Y.A. 2005b. Resettlement and risk: women's community work in Lesotho. Advances in Gender Research 9: 29-60. 
Braun, Y.A. 2006. Large dams as development: restructuring access to natural resources in Lesotho. In A.K. Jorgenson and E.L. Kick (eds.). Globalization and the environment. Leiden: Brill.

Braun, Y.A. 2008. 'How can I stay silent?': one woman's struggles for environmental justice in Lesotho. Journal of International Women's Studies 10(1): 5-20.

Braun, Y.A. 2011a. Left high and dry: an intersectional analysis of gender, dams, and development in Lesotho. International Feminist Journal of Politics 13(2): 141-162.

Braun, Y.A. 2011b. The reproduction of inequality: race, class, gender and the social organization of work at the site of large-scale development projects. Social Problems 58(2): 281-303.

Braun, Y.A. 2015. Interrogating large-scale development and inequality: bridging feminist political ecology, intersectionality and environmental justice frameworks. In S. Buechler and A.S. Hanson (eds.). $A$ political ecology of women, water and global environmental change. London: Routledge. Pp. 19-37.

Braun, Y.A. and L.A. McLees. 2012. Space, ownership and inequality: economic development and tourism in the highlands of Lesotho. Cambridge Journal of Regions, Economy and Society 5(3): 435-449.

Braun, Y.A. and M.C. Dreiling. 2014. Frames, boomerangs, and global assemblages: border distortions in the global resistance to dam building in Lesotho. In N.A. Naples and J.B. Mendez (eds.). Border politics: social movements, collective identities, and globalization. New York: New York University Press.

Bromber, K., J. Féaux de la Croix, and K. Lange. 2014. The temporal politics of big dams in Africa, the Middle East, and Asia: by way of an introduction. Water History 6(4): 289-296.

Buechler, S. and A. Hanson (eds.). 2015. A political ecology of women, water and global environmental change. London: Routledge.

Central Intelligence Agency (CIA). 2010. CIA World Factbook: Lesotho. Washington, DC: Central Intelligence Agency (CIA).

Cross, J. 2015. The economy of anticipation: hope, infrastructure, and economic zones in South India. Comparative Studies of South Asia, Africa and the Middle East 35(3): 424-437.

Davidsen, P. A. 2006. The making and unmaking of the politics of exceptionality: studying processes of securitisation and desecuritisation in the Orange and Okavango River basins. Masters thesis. University of Bergen.

Dreiling, M.C. and D. Darves. 2011. Corporate unity in American trade policy: a network analysis of corporatedyad political action. American Journal of Sociology 116 (5): 1514-1563.

Epprecht, M. 2000. 'This matter of women is getting very bad': gender, development and politics in colonial Lesotho. Pietermaritzburg: University of Natal Press.

Ferguson, J. 1990. The anti-politics machine: development, depoliticization, and bureaucratic power in Lesotho. Minneapolis: Minnesota University Press.

Fontein, J. 2008. The power of water: landscape, water and the state in Southern and Eastern Africa: an introduction. Journal of Southern African Studies 34(4): 737-756.

Gellert, P. and B. Lynch. 2003. Mega-projects as displacements. International Social Science Journal 55(1): 15-25.

Global Policy Network. 2006. Country Report - Lesotho. [accessed January 13 2011.] http://www.gpn.org

Harvey, D. 2006. Spaces of global capitalism: towards a theory of uneven geographical development. London: Verso.

Hassan, F.M.A. 2002. Lesotho - development in a challenging environment: a joint World Bank-African Development Bank evaluation. Washington, DC: African Development Bank and World Bank.

Hussain, M. 2008. Interrogating development: state, displacement, and popular resistance in North East India. New Delhi: Sage.

Infrastructure News. 2012. Masupha Sole back as water adviser. [accessed September 72019 ]. https://infrastructurenews.co.za/2012/11/06/masupha-sole-back-as-water-adviser 
Infrastructure News. 2016. Despite delays, Lesotho water project to be completed by 2025. [accessed September 7 2019]. https://infrastructurenews.co.za/2016/10/31/despite-delays-lesotho-water-project-to-becompleted-by-2025

Jenkins, J. 2016. Contested terrain of extractive development in the American West: using a regional political ecology framework to understand scalar governance, biocentric values, and anthropocentric values. Journal of Political Ecology 23(1): 182-196.

Kenworthy, N. 2017. Mistreated: the political consequences of the fight against AIDS in Lesotho. Nashville: Vanderbilt University Press.

Khagram, S. 2004. Dams and development: transnational struggles for water and power. Ithaca: Cornell University Press.

Kirchherr, J. and K.J. Charles. 2016. The social impacts of dams: a new framework for scholarly analysis. Environmental Impact Assessment Review 60: 99-114.

Lesotho Highlands Development Authority (LHDA). 1986. LHDA order of 1986. Maseru, Lesotho: Lesotho Government Gazette Extraordinary.

Letsie, D. and P. Bond. 2010. Debating supply and demand characteristics of bulk infrastructure: LesothoJohannesburg water transfer. Background Research Series, Municipal Services Project.

Li, T.M. 2007. The will to improve: governmentality, development, and the practice of politics. Durham: Duke University Press.

Matli, M. 2004. The social impacts of a large development project: Lesotho Highlands Water Project. Master's Thesis. Bloemfontein, South Africa: University of the Free State.

Mitchell, T. 2002. Rule of experts: Egypt, techno-politics, modernity. Berkeley: University of California Press.

Molle, F., P.P. Mollinga and P. Wester. 2009. Hydraulic bureaucracies and the hydraulic mission: flows of water, flows of power. Water Alternatives 2(3): 328-349.

Mosse, D. 2004. Is good policy unimplementable? reflections on the ethnography of aid policy and practice. Development and Change 35(4): 639-671.

Mosse, D. 2005. Cultivating development: an ethnography of aid policy and practice. London: Pluto Press.

Murray, C. 1981. Families divided: the impact of migrant labour in Lesotho. Cambridge: Cambridge University Press.

Panel of Environmental Experts (POE). 1991. Report to LHDA and the World Bank. Maseru, Lesotho: Lesotho Highlands Development Authority.

Peet, R. and M.J. Watts (eds.). 2004. Liberation ecologies. London: Routledge.

Perreault, T. 2013. Dispossession by accumulation? mining, water and the nature of enclosure on the Bolivian Altiplano. Antipode 45(5): 1050-1069.

Pottinger, L. 1996. Police kill striking dam workers in Lesotho. World Rivers Review 11(4): 3-6.

Purcell, M. 2008. Recapturing democracy: neoliberalization and the struggle for alternative urban futures. London: Routledge.

Rousselin, M. 2018. A study in dispossession: the political ecology of phosphate in Tunisia. Journal of Political Ecology 23(1): 20-39.

Roy, A. 2000. The algebra of infinite justice. New Delhi: Penguin.

Scudder, T. 2006. The future of large dams: dealing with social, environmental, institutional and political costs. London: Earthscan.

Scudder, T. 2012. Resettlement outcomes of large dams. In C. Tortajada, D. Altinbilek and A.K. Biswas (eds.). Impacts of large dams: a global assessment. Berlin, Heidelberg: Springer.

Sechaba Consultants. 1994. Poverty in Lesotho 1994: a mapping exercise. Working Document. Maseru, Lesotho: Government of Lesotho.

Smith, N. 2008. Uneven development: nature, capital and the production of space. Athens: University of Georgia Press. 
Thamae, M.L. and L. Pottinger (eds.). 2006. On the wrong side of development: lessons learned from the Lesotho Highlands Water Project. Maseru: Transformation Resource Centre.

Tilt, B., Y.A. Braun and H. Daming. 2009. Social impacts of large dam projects: a comparison of international case studies and implications for best practice. Journal of Environmental Management 90: S249-S257.

Tshabalala, M. and S.D. Turner. 1989. 1988 Socio-economic census of the Lesotho Highlands Water Project phase $1 A$ areas. Volume I, Main Report. Maseru, Lesotho: LHDA.

United Nations Lesotho. 2007. United Nations development assistance framework 2008 -2012. Maseru: United Nations.

Weszkalnys, G. 2014. Anticipating oil: the temporal politics of a disaster yet to come. The Sociological Review 62(S1): 211-235.

World Bank. 2010. Project performance assessment report: Lesotho Highlands Water Project, phase 1B (Loan 4339-LSO) Community Development Support Project (Credit 3308-LSO). Washington, DC: World Bank.

World Commission on Dams (WCD). 2000. Dams and development: a new framework for decision-making: the report of the World Commission on Dams. London: Earthscan. 